\title{
Pneumologia
}

\section{Shifting to the ambulatory patient-centered tuberculosis care model in Romania - preliminary results of the pilot project conducted in Marius Nasta Institute of Pneumology dispensaries, January-December 2020}

Ioana Munteanu ${ }^{1, *}$, Cristian $\mathrm{Popa}^{2}$, Cristina Popa ${ }^{2}$, Cristina Cazacu ${ }^{3}$, Andreea Pleșită ${ }^{3}$, Carmen Teoibas ${ }^{4}$,

Nicoleta Cioran ${ }^{5}$, Ramona Nedelcu' ${ }^{1}$, Daniela Valceanu ${ }^{6}$, Florentina Furtunescu' ${ }^{6}$, Ámalia Serban $^{7}$, Beatrice Mahler $^{8}$

1 "Marius Nasta" Institute of Pneumophysiology Bucharest, Bucharest, Romania

2"Marius Nasta" Institute of Pneumophysiology Bucharest, District 6 Dispensary, Bucharest, Romania

3"Marius Nasta" Institute of Pneumophysiology Bucharest, District 5 Dispensary, Bucharest, Romania

4"Marius Nasta" Institute of Pneumophysiology Bucharest, District 4 Dispensary, Bucharest, Romania

5"Carol Davila" University of Medicine Bucharest, Bucharest, Romania

${ }^{6}$ National Institute of Public Health Bucharest, Bucharest, Romania

${ }^{7}$ Ministery of Health, Medical Assistance Department, Bucharest, Romania

8“Marius Nasta" Institute of Pneumophysiology Bucharest, "Carol Davila” University of Medicine Bucharest, Romania

Abstract

\section{English:}

Reversing the concept of the Romanian medical system in terms of approaching patients with tuberculosis (TB) and removing them from a hospital-centred system into a more friendly outpatient system, closer to their needs, is one of its challenges. Preliminary data of this project show that through minimal and consistent investments the diagnosis, treatment and monitorisation can be made exclusively in the outpatient department for these patients.

Keywords

\section{Trecerea la modelul de îngrijire a tuberculozei în ambulatoriu, centrat pe pacient în Romania - rezultatele preliminare ale proiectului pilot desfăsurat in ianuarie - decembrie 2020 în dispensarele Institutului de Pneumologie "Marius Nasta"}

Rezumat

\section{Romanian:}

Inversarea conceptului sistemului medical romanesc în ceea ce priveste abordarea pacienților cu tuberculoză și scoaterea acestora dintr-un sistem centrat pe internare intr-un sistem ambulator mai prietenos si mai apropiat de nevoile lor este una din provocările acestuia. Datele preliminare ale acestui proiect, arată că prin intermediul unor investitiii minine și consecventă se poate realiza diagnosticul, tratamentul și monitorizarea exclusiv în ambulator a acestor pacienti.

Cuvinte-cheie

tuberculoza $\bullet$ tratament in ambulator $\cdot$ proiect pilot $\cdot$ rezultate preliminare

Romania is one of the 18 European countries (Armenia, Azerbaijan, Belarus, Bulgaria, Estonia, Georgia, Kazakhstan, Kyrgyzstan, Latvia, Lithuania, the Republic of Moldavia, Romania, the Russian Federation, Tajikistan, Turkey,
Turkmenistan, Ukraine and Uzbekistan) affected by the burden of tuberculosis (TB) with an increase in notification rates, that is, over 8 cases per 100,000 inhabitants and high incidence of MDR/XDR TB. 
However, in the last decade, we have made significant progress in TB control, which led to a decrease in the incidence and mortality rate of TB by $5.5-5.5 \%$ per year. For example,

- The TB incidence rate has decreased continuously since 2002 with a total percent of $59.8 \%$, resulting in an incidence rate of $57.4 \% 000$ in 2019 and of $37.9 \% 000$ in 2020 .

- The TB prevalence rate has also decreased continuously since 2002 with a total percent of $54.5 \%$, resulting in a prevalence rate of $62 \% 000$ in 2020 .

- The TB mortality rate has also decreased continuously since 2002 with a total percent of $60.95 \%$, resulting in a mortality rate of $4.1 \% 000$ in 2019 .

The diagnosis and treatment with new drugs for multidrugresistant tuberculosis (MDR-TB) has increased. The prevalence of primary MDR-TB has decreased from $3.2 \%$ to $1.6 \%$ among new TB cases. In the last 5 years (2013-2017), the notification rate of MDR-TB decreased on average by $11 \%$ per year, from 2.9 to 1.8 cases of MDR-TB per 100,000 inhabitants.

HIV testing has increased from $62 \%$ to $83 \%$, while the prevalence of HIV associated with TB decreased from $2.6 \%$ to $2.1 \%$.

The success rate of treatment for cases of TB (new and recurrent) remained at around $85 \%$ (higher than the regional and EU/EEA averages of $77 \%$ and $75 \%$, respectively), while the success rate of MDR-TB increased from $23 \%$ to $38 \%$, being significantly lower compared to regional and EU/EEA averages of $55 \%$ and $41 \%$, respectively.

These good results achieved by Romania qualify the country as a good candidate for the development of a TB patientcentred model of care.

There is a lot of good practice evidence, from around the world and from the European Region of the World Health Organization (WHO), which shows that integrated and patient-centred systems for TB-patient-care are associated not only with better health outcomes but also with substantial cost savings for the health system (1).

In addition, WHO reports and evaluations propose various models and pilot programmes to test the service reform. In this way, care is closer and more accessible to the people it serves, which means that it is more likely to be used for the benefit of patients. This requires the development of outpatient and community services to increase their planning, implementation and monitoring capacity (2).

The project, which is the subject of this article, is carried out in the Dispensaries 4, 5 and 6 belonging to the 'Marius Nasta' Institute, with the support of the Ministry of Health $(\mathrm{MoH})$; National Program for Prevention, Surveillance and Control of Tuberculosis (PNPSCT); National Institute of Health (INSP); international consultation provided by the WHO Regional Office for Europe (WHO-EURO); national level consultation; the Global Fund to Fight AIDS, Tuberculosis and Malaria and an NGO Romanian Angel Appeal (RAA).

The project is part of the Grant Agreement between the $(\mathrm{MoH})$ Ministry of Health and the Global Fund to Fight AIDS, Tuberculosis and Malaria with No. SP 1.799 of 14.02.2019 'Addressing the challenges of the health system on tuberculosis control in Romania', which has envisaged a variety of proposed activities, such as the following:

- Expansion and strengthening of National Coordination Committed CNC- FG (CCM) secretary;

- Setting up the UPPI UNIT (MoH-NPHI);

- Mid-term NSP evaluation followed by revision and extension of NSP by 2025;

- Enhancement of MoH capacity in procurement and supply chain systems for NPHP, including NTP;

- Development of a comprehensive M\&E framework for TB control; and

- Preparation and implementation of ambulatory care reform in TB field.

The methodology of the project 'Shifting to the ambulatory patient-centered TB care model' is an original one and was approved by the MoH (Order No. 590/7 April 2020 (3)).

\section{Purpose}

The purpose of the project is to demonstrate the feasibility of diagnosing and treating patients with TB in TB dispensaries, set up by the 'Marius Nasta' Institute, and to increase their capacity to manage patients with smear-negative TB, avoiding hospitalisations if they are not absolutely necessary.

Pilot development period is 12 months (6 January 2020-31 December 2020).

Due to the restrictions induced by the SARS-COV-2 pandemic, which imposed limitation on the number of consultations and beds for patients with TB in July, we decided to include patients with smear-positive TB who had conditions of isolation at home, an inclusion criterion which was added later.

\section{Objectives}

\section{General objectives}

The general objectives of the study are as follows:

1. Treatment of at least $65 \%$ of patients with smear-negative $\mathrm{TB}$, from the Bucharest region, as an outpatient in the three dispensaries of the pilot project. 
2. Decreasing the hospitalisation rate by $65 \%$ for patients with smear-negative TB, admitted in the 'Marius Nasta' Institute, until the end of 2020 .

\section{Operational objectives}

The operational objectives of the study are as follows:

1. Treatment exclusively as an ambulatory of a minimum of 200 patients with smear-negative TB from the Bucharest region in the TB dispensaries of the 'Marius Nasta' Institute, selected for the pilot.

2. To maintain the compliance treatment rate of patients with TB treated exclusively as ambulatory similar to the one calculated in 2018 , which was about $98 \%$.

\section{Expected results}

The expected results of the study are as follows:

1. To ensure a success treatment rate of $85 \%$ for ambulatory patients with TB, treated in the dispensaries involved in the pilot project.

2. To maintain an abandon rate lower or similar to that at the country level calculated in 2018.

3. To maintain a loss rate lower or similar to that at the country level calculated in 2018

In this article, we intend to present the results of the project at 1 year after implementation of the conditions in which the SARS-COV-2 pandemic brought a series of challenges regarding its development according to the methodology initially established.

\section{Material and method}

The methodology intends to create a model of TB care in TB dispensaries of the 'Marius Nasta' Institute in Bucharest. Patients can come to the dispensaries as a TB suspect, by their own initiative or guided by another medical service (family doctor, guard room, other medical speciality) or nonmedical service (social centre).

\section{Inclusion criteria}

Inclusion criteria were as follows:

- The patient is domiciled in Bucharest or in the neighbouring communes attached to the dispensaries.

- The condition of the patient does not represent a medical emergency.

- The patient does not meet the hospitalisation criteria.

- The patient is diagnosed as a TB case.
- Administration of antituberculosis treatment to the patient through the TB dispensary of the 'Marius Nasta' Institute has already commenced.

- Isolation conditions are available for the patient at home.

The case definitions, the diagnosis, treatment and evaluation recommendations - established by the Methodological Guide for the Implementation of the National Tuberculosis Prevention, Surveillance and Control Program, Bucharest, 2015 and approved by the $\mathrm{MoH}$ through Order No. 1171/21.09.2015.4have been complied with (Figure 1) (4).

The patient signed an informal consent form upon enrolment, and the doctors were able to collect usual tests, including HIV tests, which were useful for determining the severity of the disease due to comorbidities (anaemia, increased inflammation, diabetes, liver cytolysis, HIV/TB co-infection etc.). These were settled from project funds. If there are significant changes in these parameters, patients will be hospitalised faster, thereby resulting in more efficient management of comorbidities or complications.

Medication was also provided to prevent but also to quickly manage any side effects of patients in order to avoid hospitalisation, all reimbursed from the project funds.

The project tried to provide social services by involving a social worker and a psychologist who could be approached by doctors from the dispensary whenever they needed.

\section{Results}

During the first-year evaluation, the following results were obtained.

A total of 136 cases of TB [pulmonary $(P)$ and extrapulmonary $(E P)]$ were enrolled in the project during these 12 months and distributed as follows: 51 cases (District 4 ), 36 cases (District 5) and 49 cases (District 6). Thus,

1. District $4: 34$ cases $P+17$ cases $E P$

2. District 5: 33 cases $P+3$ cases EP

3. District $6: 39$ cases $P+10$ cases EP

which represents a percentage of about $30 \%$ from all patients with TB registered in the dispensaries (Table 1). The indicator was below the estimated one $(65 \%)$, but it represents a significant progress compared to the starting point, in which the initiation of treatment for patients with TB was almost exclusively in the hospital.

A total of 93 cases of smear-negative TB $(P+E P)$ have started TB treatment exclusively at the dispensaries and were distributed as follows: 36 cases (District 4), 21 cases (District 5 ) and 36 cases (District 6). A significant increase considering that in 2018 , only 14 cases of smear-negative TB from 236 


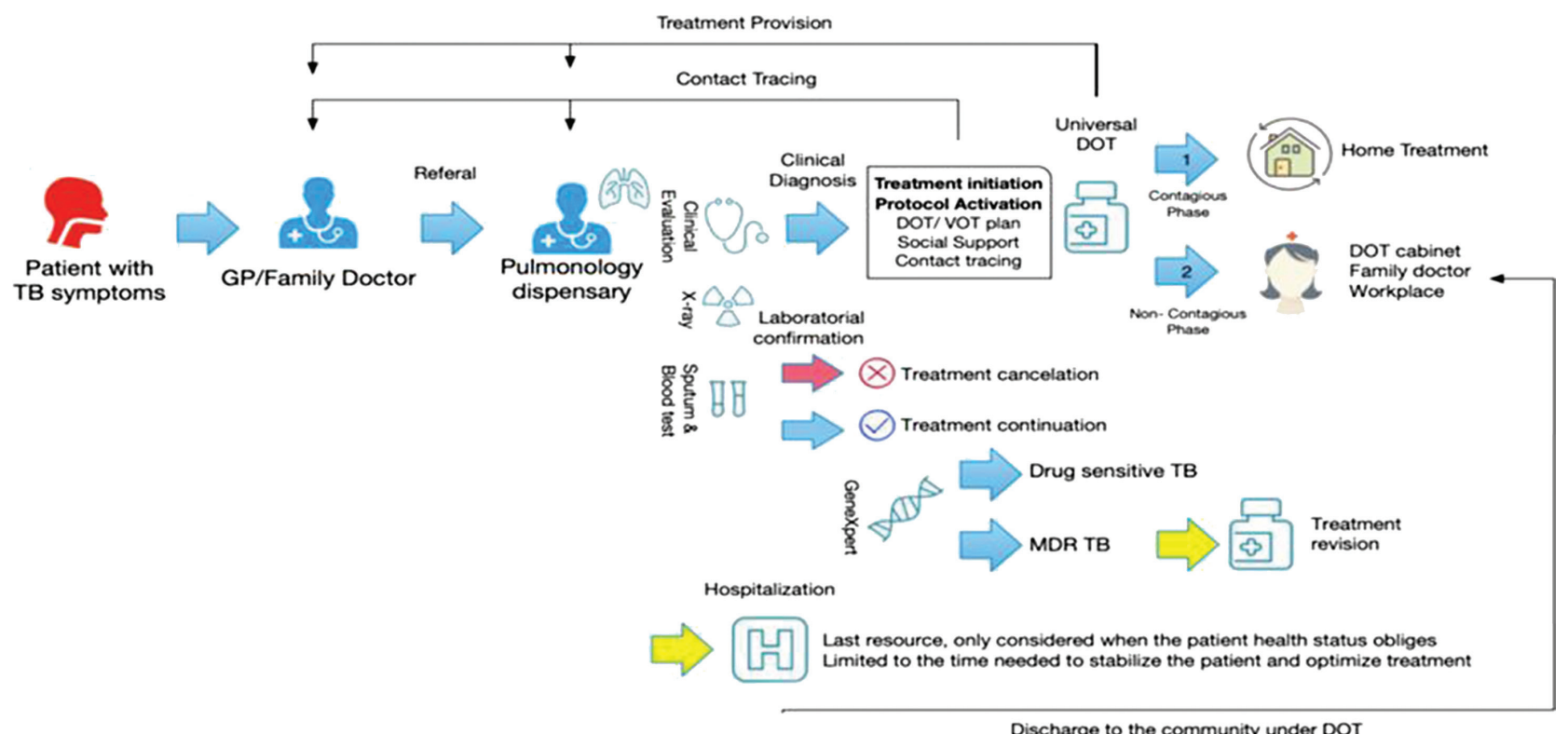

Figure 1. Patient flowchart. MDR-TB, multidrug-resistant tuberculosis; TB, tuberculosis.

Table 1. Registered patients with TB in the dispensaries

\begin{tabular}{lccc}
\hline $\begin{array}{c}\text { District } \\
\text { Dispensary (DD) }\end{array}$ & $\begin{array}{c}\text { Patients with smear-negative and } \\
\text { smear-positive TB who began } \\
\text { treatment in DD }\end{array}$ & $\begin{array}{c}\text { Total patients } \\
\text { registered in } \\
\mathbf{2 0 2 0}\end{array}$ & $\begin{array}{c}\text { Percentage of patients with negative and positive TB } \\
\text { who started treatment in DD out of the total number of } \\
\text { registered patients }\end{array}$ \\
\hline 4 & 51 & 162 & 31.48 \\
5 & 36 & 135 & 26.67 \\
6 & 49 & 155 & 31.61 \\
Total & 136 & 452 & 30.09 \\
\hline
\end{tabular}

DD: District dispensary; TB: Tuberculosis.

Table 2. Patients with smear-negative TB

\begin{tabular}{lccc}
\hline DD & $\begin{array}{c}\text { Patients with smear-negative TB who } \\
\text { began treatment in DD }\end{array}$ & $\begin{array}{c}\text { Total patients registered } \\
\text { in } \mathbf{2 0 2 0}\end{array}$ & $\begin{array}{c}\text { Percentage of patients without TB who started treatment in DD } \\
\text { from the total number of smear-negative patients registered (\%) }\end{array}$ \\
\hline 4 & 36 & 89 & 40.4 \\
5 & 21 & 49 & 42.8 \\
6 & 36 & 79 & 45.5 \\
Total & 93 & 217 & 42.8 \\
\hline
\end{tabular}

$\mathrm{DD}$, district dispensary; TB: tuberculosis.

registered smear-negative TB cases $(5.9 \%)$ have started treatment directly in the dispensary (data from epidemiological software).

Patients with smear-negative TB represented about $43 \%$ (217/452) of the total number of patients registered at all dispensaries during the same period. The indicator was below the estimated value $(65 \%)$ but represents a significant progress compared to the starting point, in which treatment initiation of patients with TB was almost exclusively in hospital (Table 2).
In conclusion, 1 out of 4 patients with smear-negative TB recorded in 2020 started treatment in a dispensary (Table 3). The percentage of patients with smear-negative TB who started treatment in a dispensary from the total number of registered patients was $20.5 \%$ (93/425) A significant increase considering that in 2018 , only 14 cases out of 236 patients with smear-negative TB registered in the dispensaries (5.9\%) started treatment as ambulatory patients (data from TB epidemiological software). Modification of inclusion criteria by extension to patients with smear-positive TB (positive 


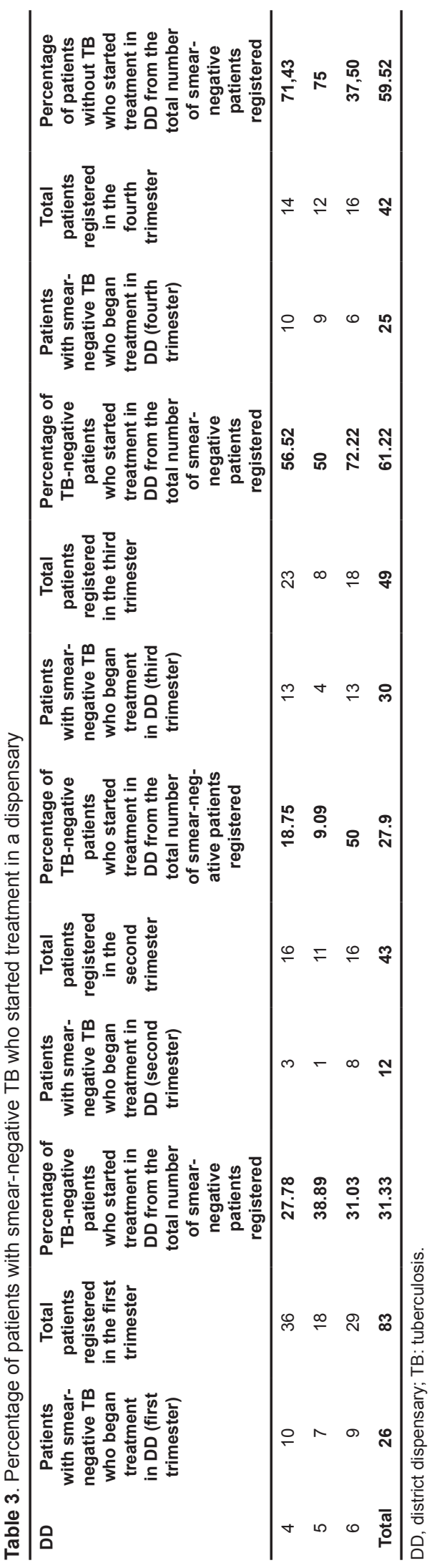

microscopy at the beginning of treatment) increased the percentage of patients treated in ambulatory care, reaching a value of $30.09 \%$ (136/425).

Low enrolment rates were registered in the first 6 months, due to the conditions imposed by the SARS-COV-2, but after the relaxation of measures, the rate increased even up to $75 \%$ where patients with TB were treated exclusively in ambulatory care, for example, in District 5 dispensary in the fourth trimester.

All patients enrolled in the pilot project received blood tests before treatment commencement or during TB monitory process according to the protocol. All available investigations were performed to establish the diagnosis of TB at dispensary level, including GeneXpert testing in order to increase the accuracy of the diagnosis.

This enrolment rate was based on the medical consultations performed by the doctors from the dispensary. In 2020, despite all the restrictions imposed by the COVID-19 pandemic, there were 13,193 consultations that led to the diagnosis of 452 patients with TB (3.43\%). The number of medical consultations decreased by approximately $30 \%$ compared to 2018 , when 18,870 consultations were registered with the diagnosis of 552 cases $(2.92 \%)$. For the detection of patients with TB, there are a significant number of symptomatic respiratory patients to evaluate. The percentage of $3.43 \%$ is below $10 \%$ because, in Romania, the incidence of TB is decreasing but is higher than that in 2018. This may reflect the fact that more severe patients came to the medical consultations despite the fear of COVID-19 infection in the dispensary on the one hand, and on the other hand, the constant use of modern methods of bacteriological diagnosis increases the diagnostic rate.

A series of side effects were also identified in eight cases presented in the table below (Table 4).

Table 4. A series of side effects were also identified in eight cases

\begin{tabular}{ccc}
\hline DD & $\begin{array}{c}\text { No. cases } \\
\text { with side } \\
\text { effects }\end{array}$ & Types of adverse reactions \\
\hline 4 & 3 & $\begin{array}{l}\text { - Quincke's oedema in PZM was replaced with LFX. } \\
\text { - Leg and upper limb oedema in association with skin } \\
\text { lesions was observed, requiring discontinuation of } \\
\text { treatment and hospitalisation for further investigation. } \\
\text { - For hepatic cytolysis, supportive medication was } \\
\text { administered. }\end{array}$ \\
5 & 1 & $\begin{array}{l}\text { - Allergic reaction to RMP manifested in the form of } \\
\text { erythematous, pruritic skin plaques, which required } \\
\text { the definitive removal of the antibiotic from the thera- } \\
\text { peutic scheme by adopting an individualised regimen. }\end{array}$ \\
6 & 4 & $\begin{array}{l}\text { - For hepatic cytolysis, supportive medication was } \\
\text { administered alongside temporary discontinuation } \\
\text { of treatment. }\end{array}$ \\
Total & 8 &
\end{tabular}


Table 5. The final treatment evaluations recorded in December 2020

\begin{tabular}{cccccc}
\hline DD & $\mathbf{2 0 2 0}$ & Evaluate as a cure or complete treatment & Denied as TB & Treatment discontinuation, abandon, loss & Continue treatment \\
\hline 4 & 51 & 13 & 3 & 1 & 36 \\
5 & 36 & 8 & 0 & 1 & 27 \\
6 & 49 & 12 & 2 & 0 & 35 \\
Total & $\mathbf{1 3 6}$ & $\mathbf{3 3}$ & $\mathbf{5}$ & $\mathbf{2}$ & $\mathbf{9 8}$ \\
\hline
\end{tabular}

$\mathrm{DD}$, district dispensary; TB: tuberculosis.

Treatment compliance measured as the percentage of missed doses, according to trimestral reports, was $98 \%$.

During the study period, five cases were denied: two cases in District 6 dispensary and three cases in District 4 dispensary confirm the fact that the differential diagnosis of the patients with smear-negative TB is a very difficult one, and further investigations are needed in this regard.

The final treatment evaluations recorded in December 2020 are reported in Table 5.

\section{Discussions}

In the last years, the recommendations of the WHO have been aiming at assessing the need for developing patientcentred services by strengthening the capacity of ambulatory and community services on diagnosis, treatment and monitoring of patients with TB, since this would enhance the treatment compliance and cure rate of these patients (5). The appropriate model of care is the one that ensures that patients with TB have the right to care, at the right time, by the right team and in the right place, taking into account the general context and location (6).

The results of our study are in line with WHO recommendations. In the dispensaries, approximately $43 \%$ of patients with smear-negative TB (93 patients) started exclusive ambulatory treatment. The total number of outpatients increased, including those with smear-positive TB, reaching a value of $30.8 \%$ (136) for those registered in 2020 . So, only one in four patients started ambulatory treatment, with $75 \%$ in District 5 in the fourth trimester.

Ensuring the possibility of laboratory tests collecting at the beginning of treatment and during monitoring has increased the confidence of colleagues in the dispensary regarding the initiation of outpatient treatment. During the project, only a limited number of side effects were registered, which could be managed in an outpatient setting (a single patient sent for hospitalisation) due to the possibility of administering preventive and curative medication in ambulatory conditions. The problem of the differential diagnosis of patients with smear-negative TB remains. A total of five cases $(3.76 \%)$ were denied treatment and this necessitated the analysis of the possibility of performing additional investigations in the outpatient setting for both diagnosis and monitoring. The creation of fast-track circuits would strengthen the diagnostic and monitoring capacity of the patient with TB and would induce the reduction of waiting time and the impact of stigma on the patient.

There were also two patients with abandonment issues and lost records $(1.47 \%)$. Far below the national average of this category $(4 \%)$ but in conditions of social distancing imposed by the SARS-COV-2 pandemic which will probably last longer and not only of it, the identification and usage of other methods to ensure supervised monitoring of treatment is absolutely necessary.

The treatment compliance was 98\% similar to that of 2018 when the majority of patients received outpatient treatment in the continuation phase, with less number of visits.

Social and psychological services have not been accessed by colleagues in the dispensary, and they were not necessary until now. Providing information regarding the transmission of the disease and protecting the family (the doctor being trained in this regard) and keeping the patient in a family environment can ensure the success of treatment. It does not exclude special situations in which these services are needed, and they should be constantly a part of care for patients with TB.

\section{Conclusions}

There is significant addressability to each of the district dispensaries, that will continue to increase as a result of the approval and implementation of the joint order of the $\mathrm{MoH}$ and the Ministry of Labor (Order No. 2,087/1,822/2020 (7)) for monthly food allowance for people diagnosed with TB, who are treated on ambulatory care.

Ambulatory diagnosis and treatment may be a clinically feasible option if funds are provided for the settlement of routine tests, supportive medication and treatment of adverse reactions.

The care system must be based on a team-based approach, including trained providers in the field of social care, allowing treatment decisions to be made that address an integrated 
range of clinical, socio-economic and structural issues faced by patients (8). Strengthening links with social care services in town halls and with NGOs is absolutely necessary in order to provide this type of care to patients in vulnerable categories.

\section{Author Contributions}

All the author had the same contribution.

\section{Conflicts of Interest}

No conflicts of interest.

\section{References}

1. Improving payment mechanisms to support a new delivery model for TB care in Romania. Available from: https://www.aeek. hu/documents/20182/188991/Model-of-care_ROM_2017_May. pdf/2bf02e1e-2b3e-3c53-5895-c8c1342992b6.
2. Available from: http://www.raa.ro/wp-content/uploads/2016/ 05/2.-WHO-report-Ambulatory-care-reform-in-TB-care-Romania.pdf.

3. ORDIN nr. 590 din 7 aprilie 2020 pentru aprobarea Metodologiei de implementare a proiectului-pilot privind modelul de îngrijire în sistem ambulatoriu a pacienților cu tuberculoză din România, MONITORUL OFICIAL nr. 304 din 10 aprilie 2020

4. Ghid Metodologic de Implementare a Programului National de Prevenire, Supraveghere si Control al Tuberculozei, Bucuresti 2015 aprobat prin, Ministerul Sănătății a emis Ordinul nr. 1171/21.09.2015.

5. Available from: http://www.euro.who.int/_data/assets/pdf file/0004/342373/TB_Content_WHO_PRO_eng_final.pdf?ua=1.

6. A People-Centred Model of TB Care. Available from: http://www. euro.who.int/_data/assets/pdf_file/0004/342373/TB_Content_ WHO_PRO_eng_final.pdf?ua=1.

7. Ordinului comun al Ministerului Sănătatii și Ministerului Muncii nr. ORDINUL nr. 2.087/1.822/2020 Indemnizația lunară de hrană cuvenită persoanelor diagnosticate cu tuberculoză, tratate în ambulatoriu.

8. The World Health Report; 2008. Available from: https://reliefweb. int/report/world/world-health-report-2008-primary-health-carenow-more-ever. 